\title{
Investigations on pelagic food webs in mountain lakes - aims and methods
}

\author{
Viera STRAŠKRABOVÁ*, Cristiana CALLIERI ${ }^{1}$, Presentacion CARRILLO ${ }^{2}$, Luis CRUZ-PIZARRO ${ }^{2}$, Jan FOTT $^{3}$, \\ Petr HARTMAN, Miroslav MACEK, Juan Manuel MEDINA-SÁNCHEZ ${ }^{4}$, Jirí NEDOMA and Karel ŠIMEK
}

Hydrobiological Institute, Czech Academy of Sciences and University of South Bohemia, Faculty of Biology, Na sádkách 7, 37005

Č. Budějovice, Czech Republic

${ }^{1}$ C.N.R. Istituto Italiano di Idrobiologia, L.go V. Tonolli 50, 28922 Verbania Pallanza, Italy

${ }^{2}$ Instituto del Agua, Universidad de Granada, 18071 Granada, Spain

${ }^{3}$ Charles University, Faculty of Science, Viničná 7, 12400 Praha Czech Republic

${ }^{4}$ Departamento de Biología Animal y Ecología, Universidad de Granada, 18071 Granada, Spain

*e-mail corresponding author: verastr@hbu.cas.cz

\begin{abstract}
A methodical approach for the assessment of pelagic biomass and the main carbon fluxes in remote and hardly accessible mountain lakes was elaborated and tested. Number and biomass of bacteria (BAC), autotrophic picoplankton (APP), heterotrophic nanoflagellates $(H N F)$, ciliates (CIL), phytoplankton (PHY), zooplankton smaller than $40 \mu \mathrm{m}(\mathrm{ZOOS})$ and zooplankton larger than $40 \mu \mathrm{m}$ (ZOOL) were investigated regularly during two ice-free periods in 13 European mountain lakes ( $1^{\text {st }}$ level approach - fixed samples elaborated in specialized laboratories). Carbon fluxes measured in 9 lakes included: primary production, exudation by PHY and $B A C$ uptake of exudates, BAC production, elimination of BAC. These processes were measured in the field by specialized teams $\left(2^{\text {nd }}\right.$ level approach). The ranges of values found in mountain lakes were evaluated and possible methodical and interpretative errors discussed. BAC were a significant component of pelagic biomass. The intercomparison between different partners showed differences in bacterial counts lower than $10 \%$, whereas the mean cell volumes measured fluctuated by more than $40 \%$. APP was never found in a significant quantity, except in one lake. HNF and CIL, though regularly found, were usually scarce and only occasionally significant in terms of biomass. The main components of pelagic biomass were BAC, PHY and ZOOL+ZOOS, except for acidified lakes, where zooplankton was very low. In oligotrophic mountain lakes, the percentage of extracellular production in the total primary production was considerable. Bacterial abundance and production often reached values quite comparable with the situation found in lowland mesotrophic lakes during winter.
\end{abstract}

Key words: microbial loop, phytoplankton, zooplankton, mountain lakes, methods, carbon fluxes

\section{INTRODUCTION}

Mountain lakes, remote from pollution sources, hardly accessible, with little human activity in catchments, are often oligotrophic though they might be loaded by pollutants and nutrients from the air via long distance transport. Their ecosystems are exposed to harsh abiotic conditions, low temperature, long ice and snow cover, varying hydrology, often fluctuating suddenly and stochastically. Moreover, due to low mineral content in the areas with crystalline bedrock, they are sensitive to acidification (Mosello et al. 1998). However, they still have a high degree of homeostasy and the chemistry of rainwater loaded to their catchments is changed due to biological processes occurring in the lake and in catchment soils. They can integrate sudden and varying changes of input and serve thus as sensors and indicators of air pollution and climate change (Patrick et al. 1998).

Pelagic food webs of oligotrophic low-alkalinity mountain lakes are poor and rather simple. Filtering zooplankton may be very scarce (Fott et al. 1992). Due to low nutrients, phytoplankton biomass is low and the third main pelagic component, bacteria, becomes more important in the total pelagic biomass with decreasing trophy (Straškrabová \& Šimek 1993).
It might be expected that small pico-size autotrophic organisms outcompete the larger ones in oligotrophic environments as the increase of the surface-to-volume ratio constitutes an advantage for the diffusion of nutrients (Chisholm 1992; Stockner et al. 1999). Picoplankton in oligotrophic lakes with poorly filtering metazooplankton are grazed by protozoan grazers - heterotrophic flagellates, ciliates and very often by mixotrophic flagellates as observed in other oligotrophic environments (Jones 1994).

A quantitative assessment of the biomass of all the above mentioned pelagic components was regularly performed in 12 selected lakes in the framework of the MOLAR project (Patrick et al. 1998) - "1 $1^{\text {st }}$ level approach". In two of the lakes (La Caldera, Sierra Nevada and Redó, Pyrenees), pelagic food webs including heterotrophic microbial components had already been studied before 1996, during the EC project AL:PE 2 (EV5V-CT92-0205), by teams from the University of Granada (Reche et al. 1996, 1997, 1998; Tóth et al. 1995), and the University of Barcelona (Felip 1997). Results of the first year of the MOLAR project were summarised for several lakes (Straškrabová et al. 1999b).

It is hypothesized that the importance of bacteria and the microbial loop in plankton will increase with the de- 
creasing trophy and/or acidification, not only in terms of biomass, but also in terms of carbon fluxes. Bacterial activity in mountain lakes is likely to be controlled by temperature, as in arctic lakes (Laybourn-Parry et al. 1995) and in winter or in the cold hypolimnion of temperate oligo- to mesotrophic lakes (Simon 1998). However, the specific (per cell) activity of bacteria in mountain lakes was found to be similar or even higher than that of bacteria in meso- to eutrophic lowland lakes (Straškrabová \& Šimek 1988). Though the primary production of mountain lakes (Tilzer 1972) is low, and in alpine catchments with low soil cover the allochthonous input of organic carbon to lakes cannot be expected to be not significant (Baron et al. 1991), the amount of extracellular production of phytoplankton (not measured by conventional methods) might be an important source of substrate for pelagic bacteria (Reche et al. 1996). The carbon fluxes were measured in 9 MOLAR lakes using the " $2^{\text {nd }}$ level approach", viz. primary production, exudation and bacterial uptake of exudates, bacterial production and elimination of bacteria.

\section{METHODS}

\subsection{Sampling strategy and technique}

In 13 lakes from 23 sites studied in the MOLAR project, pelagic food webs were investigated to the $1^{\text {st }}$ level (in Laghetto only phyto- and zooplankton). The lakes represented two west-east transects: northern from Lochnagar (Scotland) through Stavsvatn and Øvre Neådalsvatn (Norway) to Chuna (Kola peninsula, Russia), and southern - from La Caldera and Redó (Spain) through Paione Superiore, Laghetto, Jöri and Gossenkölle (Italian, Swiss and Austrian Alps) to Nižné Terianske, Starolesnianske and Długi (Slovak and Polish Tatra).

In Øvre Neådalsvatn, La Caldera, Redó, Paione Superiore, Jöri (without primary production), Gossenkölle, Starolesnianske and Długi, $2^{\text {nd }}$ level measurements of carbon fluxes were also performed. The Location and basic characteristics of all the MOLAR lakes and their catchments as well as data on lake water chemistry and atmospheric loading are summarised by The MOLAR Water Chemistry Group (1999, this issue).

Samples were taken at the deepest site in the lake during two ice-free periods (1996 and 1997), at least three times in each season, synchronized with sampling for chemical analyses and temperature profiling. A van Dorn-type sampler of 2 to 3 litres volume was used for sampling all the components except large zooplankton, i.e. bacteria (BAC), heterotrophic nanoflagellates (HNF), ciliates (CIL) and small zooplankton (ZOOS). A quantitative net ( $200 \mu \mathrm{m}$ mesh size $)$ of the Apstein type, with a mouth-reducing cone, opening diameter $0.19 \mathrm{~m}$, was used for large zooplankton (ZOOL).

In each lake, a layer below the surface (upper end of sampler $1 \mathrm{~m}$ below the surface) and above bottom (the lower end of sampler $1 \mathrm{~m}$ above bottom) were sampled.
In lakes deeper than $6 \mathrm{~m}$, a third sample from a middle layer (or from the thermocline, if any) was also taken. For special measurements, additional layers and more frequent sampling was performed.

ZOOS samples were concentrated by a plankton net of $40 \mu \mathrm{m}$ mesh size, from at least 10 litres sampled in respective depths. For ZOOL, several vertical hauls (depending on zooplankton density) were taken at the deepest point with a towing speed of about $0.3 \mathrm{~m} \mathrm{~s}^{-1}$. A sample for estimating zooplankton biomass (ZOOB) was taken in the same way. All samples except for ZOOB were preserved immediately and stored in the dark.

\subsection{Bacterial abundance and biomass (BAC)}

Samples preserved by prefiltered formaldehyde (final concentration $2 \% \mathrm{vol} / \mathrm{vol}, 5 \mathrm{ml}$ of $37-40 \%$ formaldehyde per $100 \mathrm{ml}$ of sample) were used. $2-10 \mathrm{ml}$ subsamples were filtered through $0.2 \mu \mathrm{m}$ pore size black polycarbonate filters (Poretics or Nuclepore) and stained with the fluorochrome 4', 6-diamino-2-phenylindole (DAPI, final concentration $0.2 \% \mathrm{wt} / \mathrm{vol}$ ) according to Porter \& Feig (1980). A solution of DAPI $0.01 \mathrm{~g}$ per 10 $\mathrm{ml}$ was used, $50 \mu \mathrm{l}$ per $2 \mathrm{ml}$ of subsample. Samples were counted using an epifluorecence microscope equipped with the filter set for DAPI (specification of filter depends on type of microscope). At least 400 bacterial cells were counted on at least 10 fields of the filter. Bacterial numbers were calculated as follows:

$$
N=\frac{A \times n}{a \times 0.95 \times v}
$$

where $N=$ number of bacteria per ml of sample, $A=$ filtration area, $n=$ number of bacteria counted in 10 fields, $a=$ area of 10 fields, $v=$ volume of sample filtered $(0.95$ is a correction factor for the fixative added).

Between 400 and 600 cells were sized by semiautomatic image analysis system and volumes calculated as described by Psenner (1993). Special attention was paid to the appropriate evaluation of filamentous bacteria, which are frequently found in alpine lakes.

Bacterial carbon biomass was calculated according to the allometric relationship between cell volume (V) and carbon content $(C)$ reported by Norland (1993):

$$
C=120 \times V^{0.72}(\text { in fg per cell })
$$

\subsection{Autotrophic picoplankton (APP)}

Picocyanobacteria and eucaryotic autotrophic picoplankton (up to the cell size of $2 \mu \mathrm{m}$ ) can be quantified and distinguished according to the presence of specific pigments via epifluorescence microscopy (for details of the appropriate filter set see MacIsaac \& Stockner 1993). Picocyanobacteria must be fixed before being counted by epifluorescence techniques for two main reasons: the addition of the proper fixative overcomes the possibility of cell destruction, and also ensures the rapid settling of the cells in the thin oil layer between 
membrane and coverslip. Nevertheless, water samples fixed either with formaldehyde or glutaraldehyde and kept refrigerated in the dark cannot be retained for a long time (max 1 week) and immediate sample processing was strongly recommended. In the literature there is still no agreement as to the most appropriate preservatives to be used (Hall 1991; Kuuppo-Leinikki \& Kuosa 1989; Bloem et al. 1986) The use of $20 \%$ formaldehyde has the advantage of being less stressful for the cells than the $40 \%$ solution, and not so diluted as to necessitate the addition of a large volume of fixative which could exert considerable osmotic effects. The sodium cacodilate buffer contains arsenic, and ensuring killing effect on the heterotrophic picoplankton, and maintains the $\mathrm{pH}$ of the solution at around 7 (Hayat 1981). Depending on the APP concentration, 2-10 $\mathrm{ml}$ of formaldehyde-cacodylate preserved sample $(5 \mathrm{ml}$ of $20 \%$ formaldehyde-cacodylate per $95 \mathrm{ml}$ of sample) was concentrated onto $0.2 \mu \mathrm{m}$ pore-size filters (black $\mathrm{Nu}$ clepores or Anopores). Picocyanobacteria were distinguished from eucaryotic APP by their specific yellow autofluorescence of phycoerythrin (blue excitation, filter set for Zeiss Axioplan - BP 450-490/FT 510/LP 520). For calculation of numbers a factor of 0.95 for volume correction of added fixative was used. Cell volumes were calculated as elipsoids from cell length and width. Cell volumes were converted to carbon using a conversion factor of $200 \mathrm{fg} \mathrm{C} \mathrm{mm}^{-3}$ (Weisse 1993) or appropriate factors obtained in the single laboratories (see specifications by the Authors).

\subsection{Heterotrophic flagellates abundance and biomass $(\mathrm{HNF})$}

Nanoflagellates include cells in the range of 2-20 $\mu \mathrm{m}$, usually with a clear dominance of cells $<5 \mu \mathrm{m}$. A volume of $10-50 \mathrm{ml}$ of formaldehyde preserved sample (the same as for BAC) was concentrated onto $1 \mu \mathrm{m}$ pore-size black polycarbonate filter (Poretics or Nuclepore), stained with DAPI and counted in an epifluorescent microscope (see BAC). Each flagellated individual was checked for the presence of autofluorescing plastids (switching from filter set for DAPI to the set for chlorophyll autofluorescence) to differentiate heterotrophic aplastidic (HNF) from autotrophic plastidic (ANF) forms. On the same filter, cell length and width were measured with a calibrated ocular micrometer and volumes calculated as prolate spheroids. Cell volumes were converted to carbon by a factor of $220{\mathrm{fg} \mathrm{C} \mu \mathrm{m}^{-3}}^{-3}$ (Borsheim \& Bratback 1987). For calculation of numbers a factor of 0.95 was used as a correction for the volume of added fixative. Samples were elaborated within one month after sampling at the latest.

\subsection{Ciliate abundance, biomass and taxonomic determination (CIL)}

A volume of $500 \mathrm{ml}$ samples with $5 \mathrm{ml}$ of Lugol reagent (Vollenweider 1974) was used. If elaborated later than 2 weeks after sampling, $50 \mathrm{ml}$ of $40 \%$ formaldehyde and $1 \mathrm{ml}$ of $45 \%(\mathrm{w} / \mathrm{v})$ sodium thiosulphate were added within 5 days after sampling.

The whole sample was sedimented for one week in a cylinder, stoppered with parafilm, then the upper volume of $400 \mathrm{ml}$ was gently removed. Ciliate numbers and taxonomic groups were assessed in sedimentation chambers under the inverted (Utermöhl) microscope. Cell length and width were measured and volumes calculated as prolate spheroids. Volumes of preserved ciliates were corrected for shrinkage in Lugol (to estimate "live" volumes) by a factor of 1.4 (Möller \& Geller 1993). At postfixation with formaldehyde, no additional shrinkage occurred (Wiaczkowski et al. 1994). For calculation of numbers, the correction factor for fixative added was 0.99 for Lugol preserved samples and 0.89 for the additionally postfixed samples. The conversion factor from volume biomass to carbon was $140{\mathrm{fg} \mu \mathrm{m}^{-3}}^{-3}$ (Putt \& Stoecker 1989).

\subsection{Phytoplankton (PHY)}

Phytoplankton (at least $500 \mathrm{ml}$ ) were sampled and stored in well washed PET (polyethylenterephtalate) bottles, which were very suitable for transportation being light, tight, unbreakable and impermeable for iodine. Samples were preserved by Lugol (Vollenweider 1974) and checked every two weeks for colour (Lugol added if necessary). Elaboration was done within 2 months.

Samples were pre-sedimented in $500 \mathrm{ml}$ cylinders. By siphoning the supernatant liquid, samples were concentrated to 0.1 or 0.2 of the original volume. This step could have been omitted only for lakes with abundant phytoplankton, which are rather an exception among high mountain lakes. Counting and measuring were carried out in sedimentation chambers after Utermöhl (Vollenweider 1974) of $25 \mathrm{~mm}$ inner diameter and 10$30 \mathrm{~mm}$ height. An inverted microscope with objectives $10 \times, 40 \times$ and $60 \times$, equipped with phase contrast, was used for counting and measuring cells. The number of counted cells was one to several hundred per sample of main species; the optimum number was 300 . This was achieved by counting bands of known width across the centre of the counting chamber (their area being band width multiplied by the inner diameter of the chamber) or by counting squares of known area. Cell dimensions were measured using an electronic caliper connected to a PC (Legner \& Sprules 1993); about 50 cells of each taxon were measured, with measurements being repeated at each sampling date.

Results are expressed as abundance (cells $\mathrm{ml}^{-1}$ ), biovolume $\left(\mathrm{mm}^{3} \mathrm{~m}^{-3}\right)$ and organic carbon $\left(\mathrm{mg} \mathrm{m}^{-3}\right.$ or, numerically equivalent, $\mu \mathrm{g} \mathrm{l}^{-1}$ ). Individual cell volumes of main species were calculated as volumes of geometrical bodies approximating shapes of the cells (sphere, ellipsoid, cylinder, mean of an ellipsoid and a cone for droplike cells, etc.). Conversion to organic carbon was necessary when comparison of phytoplankton biomass with 
the biomass of other components of the food web was required. After reviewing the available literature (Vollenweider 1974; Reynolds 1984; Rocha \& Duncan 1985), it was decided to use the single conversion factor for all phytoplankters, namely:

$$
\text { organic } \mathrm{C}(\mathrm{mg})=\text { biovolume }\left(\mathrm{mm}^{3}\right) \times 0.2
$$

An experimental test of this a priori factor is described in the results section.

\subsection{Zooplankton (ZOOS, ZOOL, ZOOB)}

Concentrated samples for ZOOS and ZOOL preserved by formaldehyde (resulting concentration 4\%) were stored in $100 \mathrm{ml}$ plastic bottles. Before elaboration, samples were washed on a $40 \mu \mathrm{m}$ sieve. All samples of small zooplankton (ZOOS, taken by volume samplers) and many samples of large zooplankton (ZOOL, taken by vertical net hauls) were counted as a whole, without subsampling. When necessary, subsamples were taken with a $50 \mathrm{ml}$ spherical swirling flask and a displacement pipette of 1-5 ml capacity. The tip of the pipette was cut to prevent size selection of the zooplankton. Counting chambers, Sedgwick-Rafter or Utermöhl type were used and their whole content counted. The number of counted individuals per species was about 300 whenever possible but many ZOOS and some ZOOL samples did not contain as many as that. Abundance of zooplankton was expressed as individuals per cubic meter.

The biovolume of rotifers was estimated according to Ruttner-Kolisko (1977). Volumes of species which contract after preservation (Conochilus, Synchaeta) were calculated as volumes of ellipsoids. Volumes were converted to organic carbon by the factor 0.05 :

$$
\text { organic } \mathrm{C}(\mathrm{mg})=\text { biovolume }\left(\mathrm{mm}^{3}\right) \times 0.05
$$

The conversion is based on the assumed dry-to-wet weight ratio 0.1 (Pace \& Orcutt 1981) and carbon-to-dry weight ratio 0.5 .

The same procedure was used for nauplii; volumes were calculated according to the formula of M. Manca (personal communication):

$$
\text { biovolume }\left(\mathrm{mm}^{3}\right)=0.217 \times\{\text { length }(\mathrm{mm})\}^{3}
$$

The biomass of other crustaceans was estimated from their length-weight relationships (McCauley, in Downing \& Rigler 1984). The choice of the proper equation was up to the discretion of each investigator. Organic carbon was calculated as $50 \%$ of dry mass (see 3.1).

Samples for direct determination of zooplankton biomass dry weight (ZOOB) were transported alive to the laboratory in a large volume of lake water (1.5 litre). They were checked for purity, objects other than zooplankton being removed when possible. Then the samples were retained on pre-weighed nylon circles $40 \mu \mathrm{m}$ mesh size, dried at $60{ }^{\circ} \mathrm{C}$, and put into glass vials, which were closed tightly and stored. Before weighing, sam- ples were re-dried at $60{ }^{\circ} \mathrm{C}$. Care was taken that preweighing circles and weighing samples were carried out under the same conditions, with minimum exposure to open air. This was a necessary precaution because both dried circles and dried zooplankton take up moisture when exposed to the air at room temperature. After weighing, the final check for purity was done by examining the dried animals with a stereomicroscope.

\subsection{Phytoplankton primary production}

Incorporation of ${ }^{14} \mathrm{C}$ by phytoplankton cells as well as bacterial incorporation of photosynthetically produced extracellular organic $\mathrm{C}$, plus concentration of photosynthetically produced and released organic $\mathrm{C}$, not utilized by bacteria, was measured. The procedure was based on the methodical approach elaborated and experimented in the high-mountain lake La Caldera in 1993 (Reche et al. 1996).

The layers $0.5 \mathrm{~m}$ and $2 \times$ Secchi disc depth (the lower limit of the euphotic zone) were sampled, plus another three layers between. In very shallow lakes, the number of layers might be reduced to three. From the same depths, chlorophyll $(\mathrm{CH})$ and inorganic $\mathrm{C}$ (DIC) were analyzed. Samples for $\mathrm{CH}$ were filtered immediately through GF/C filters, stored with silicagel and frozen. Samples for DIC were protected from contact with air before analysis. From each depth, two dark and two light quartz-glass bottles $(100-250 \mathrm{ml})$ were filled and ${ }^{14} \mathrm{C}$-bicarbonate $(0.5 \mathrm{Mbq}$ in $50-200 \mu \mathrm{l})$ added to each, then the bottles were exposed at the sampling depths for 3-4 hours. After exposure the bottles were stored in the dark and immediately elaborated.

From each bottle $1 \mathrm{ml}$ subsample was removed and transferred into a scintillation vial with $1 \mathrm{ml}$ of $\beta$-phenethylamine for the determination of total activity (T). A defined volume of sample was then filtered through an "algal" filter (A), the filter placed in the scintillation vial and the filtrate collected. The porosity of the filter was chosen according to the locality sampled: the filter should retain phytoplankton, not bacteria $(0.8-2 \mu \mathrm{m}$ Nuclepore or Poretics). $10 \mathrm{ml}$ of filtrate was transferred to the scintillation vial with $10-100 \mu \mathrm{l}$ of $\mathrm{HCl}$ to the final concentration of $0.01 \mathrm{~N}(\mathrm{C}+\mathrm{B})$. The rest of the filtrate was preserved by formaldehyde (to final concentration $2 \%$ ) and processed later: filtered through $0.2 \mu \mathrm{m}$ filter to collect bacteria (B) and the filter placed in scintillation vials. The vials with the acidified filtrate $(\mathrm{C}+\mathrm{B})$ were opened and left overnight, then neutralized with a small volume of $\mathrm{NaOH}$. Radioactivity was measured by liquid scintillation. Values from light bottles were corrected for dark bottle values. Inorganic carbon (DIC) was determined by carbon analyzer or estimated from $\mathrm{pH}$ and alkalinity (using Gran titration) after correction by temperature and ionic strength. Chlorophyll- $a$ was measured spectrophotometrically after extraction with acetone and computed from absorbances read at 663, 647 and $630 \mathrm{~nm}$ (Jeffrey \& Humphrey 1975). 
Values are interpreted as follows: $(\mathrm{A}+\mathrm{B}+\mathrm{C})=$ gross primary production, $\mathrm{A}=$ net primary production, $(\mathrm{B}+\mathrm{C})$ = extracellular production (exudation), $\mathrm{B}=$ part of extracellular production incorporated by bacteria during the exposure.

\subsection{Bacterial production}

Bacterial incorporation of ${ }^{3} \mathrm{H}$-thymidine (THY) or ${ }^{3} \mathrm{H}$-leucine (LEU) was measured. The same layers were sampled as for primary production. Samples were processed immediately. From each depth, 5 incubation vials with a $10 \mathrm{ml}$ sample were prepared, two of them with formaldehyde added to a final concentration of $2 \%$ (blanks). To each vial, $10-100 \mu 1$ of ${ }^{3} \mathrm{H}-\mathrm{THY}$ or ${ }^{3} \mathrm{H}-\mathrm{LEU}$ was added to a final concentration of $25 \mathrm{nmol} \mathrm{l}^{-1}$. Vials were incubated at the in situ temperature in the dark for 30-60 min, then preserved by formaldehyde and stored in the cold and dark before final elaboration. Samples were filtered through $0.2 \mu \mathrm{m}$ Nuclepore or Poretics filters, and the filters rinsed 5 times with $1 \mathrm{ml}$ of ice-cold $5 \%$ trichloroacetic acid. Filters were placed in scintillation vials and scintillator added. Values were corrected for blanks and expressed in pmol $1^{-1} \mathrm{~h}^{-1}$ of THY or LEU.

\subsection{Elimination of bacteria}

Fluorescently labelled bacteria (FLB) stained with DTAF were used according to Sherr \& Sherr (1993). Total elimination in the sample was measured using the approach of Salat \& Marrasé (1994). Samples from the same depths as for primary production were used. 250 $\mathrm{ml}$ with added FLB (corresponding approximately to $1-$ $5 \%$ of natural bacterial population) was exposed in duplicates at the in situ temperature in the dark for 1 to 2 days. At the start and end of exposure subsamples were taken and preserved with formaldehyde (2\% final concentration). Samples were filtered through $0.2 \mu \mathrm{m}$ black Nuclepore filters, stained with DAPI and counted. On the same filter, total bacteria (DAPI) and FLB (filter set for acridine orange) were counted and the elimination rate calculated.

$$
G=\left(F_{0}-F_{T}\right) \frac{N}{F}
$$

where

$$
N=\frac{N_{0}+N_{T}}{2}
$$

and

$$
F=\frac{F_{0}+F_{T}}{2}
$$

$G=$ bacteria grazed per period $T ; N_{O}$ and $N_{T}$ bacterial abundance at time 0 and $T$;

$F_{0}$ and $F_{T}=$ FLB abundance at time 0 and $T$.

Elimination rate $(e)$ can be estimated as $G / N_{0}$ per time. An estimate of bacterial production rate $(p)$ could be calculated as follows:

$$
p_{a p}=\frac{\ln N_{T}-\ln N_{0}}{T}
$$

$$
p=p_{a p}+e
$$

where $p_{a p}$ is the apparent production rate (net rate, if elimination is not considered).

\section{RESULTS AND DISCUSSION}

\subsection{Number and biomass of bacteria}

Bacterial number and biomass were investigated by 5 Research Institutions in 12 mountain lakes during 2 ice-free seasons at 2 to 5 depths; they were in the ranges comparable with winter samples from meso- to eutrophic lowland lakes (Tab. 1). Numbers below 150,000 per $\mathrm{ml}$ were found in 5 lakes, whereas numbers above $1,500,000$ per $\mathrm{ml}$ occurred in 3 lakes. The extraordinary high value close to 10 million per $\mathrm{ml}$ was observed once in a lake with the inflow from a glacier (Jöri, Swiss Alps - Hinder et al. 1999a). High numbers were not always combined with high biomass. Both low and high mean cell volumes might be found in the same lake during the seasonal cycle and, occasionally, long filamentous cells were found. The maximum observed biomass was found in the sample with maximum cell volume and maximum cell length observed.

Tab. 1. Range of bacterial number and biomass in all samples from the pelagial of 12 lakes.

\begin{tabular}{lccc}
\hline Parameter & Total range & 3 lowest values & 3 highest values \\
\hline number, $10^{6} \mathrm{ml}^{-1}$ & $0.06-9.79$ & $0.06,0.08,0.11$ & $2.09,2.73,9.79$ \\
mean volume, $\mu \mathrm{m}^{3}$ & $0.01-1.46$ & $0.01,0.01,0.03$ & $0.60,0.95,1.46$ \\
mean length, $\mu \mathrm{m}$ & $0.3-4.1$ & $0.3,0.4,0.5$ & $3.1,3.9,4.1$ \\
carbon biomass, fg $\mathrm{l}^{-1}$ & $5.5-124.9$ & $5.5,8.1,10.3$ & $74.2,74.5,124.9$ \\
\hline
\end{tabular}

Intercomparison of counting bacteria and measuring cell volumes was performed in one sample from lake Redó (April 1997 under the ice) simultaneously by 5 partners (volumes measured only by 3 of them). The sample was contaminated by melting ice and contained a lot of yellowish filaments and debris. The results are summarised in table 2. Partner No. 4 used acridine orange (AO) stain instead of DAPI, and Anopore filters instead of Nuclepore. The abundance counted by different partners was within reasonable limits if the high heterogeneity of the sample is considered. The standard deviation of mean abundance determined by individual partners did not exceed $11 \%$, whereas the SD of replicate counts by each partner was higher (25-74\%), reflecting the high heterogeneity of the sample.

A comparison of the mean cell volumes measured by 3 partners showed SD of $13 \%$. As emerges from the cell volume distribution measured by partner 3 (Fig. 1), $37 \%$ of measured cells had volumes in the range of $0.08-0.16 \mu \mathrm{m}^{3}$ and another smaller peak (2.5\% of cells) was in the range of $5.12-14.5 \mu \mathrm{m}^{3}$. Similarly, the distribution of measured cell lengths (Fig. 2) showed one very high peak $(66 \%)$ in the range of $0.5-1.01 \mu \mathrm{m}$ and a smaller peak $(4.5 \%)$ within the range of $8.06-12.8 \mu \mathrm{m}$. 
The number of filamentous cells longer than $5 \mu \mathrm{m}$ reached only $8.5 \%$ of the total abundance, but the cells with volumes above $0.91 \mu^{3}$ represented more than $80 \%$ of the total volume biomass of bacteria. Since the percentage of carbon in a bacterial cell decreases with increasing cell size (Norland 1993), the share of filamentous cells in total bacterial carbon biomass will be lower than in volume biomass, but even then they will represent more than $50 \%$ of the bacterial carbon in that particular sample.

Tab. 2. Intercalibration of bacterial counting and measuring by 5 partners. Sample from Estany Redó, April 10, 1997. SD - standard deviation among replicate samples of one partner, or among partners (last row).

\begin{tabular}{cccc}
\hline Partner n. & $\begin{array}{c}\text { abundance mean } \\
\pm \mathrm{SD} 10^{6} \mathrm{ml}^{-1}\end{array}$ & $\begin{array}{c}\text { cell volume } \pm \\
\mathrm{SD} \mu \mathrm{m}^{3}\end{array}$ & $\begin{array}{c}\text { cell length } \pm \mathrm{SD} \\
\mu \mathrm{m}\end{array}$ \\
\hline 1 & $0.379 \pm 0.018$ & - & - \\
2 & $0.342 \pm 0.016$ & $0.176 \pm 0.018$ & $1.638 \pm 0.111$ \\
3 & $0.301 \pm 0.022$ & 0.140 & 0.900 \\
4 & $0.300 \pm 0.074$ & $0.179 \pm 0.042$ & $0.963 \pm 0.001$ \\
5 & $0.362 \pm 0.025$ & - & - \\
average & $0.337 \pm 0.036$ & $0.165 \pm 0.022$ & $1.167 \pm 0.409$ \\
\hline
\end{tabular}

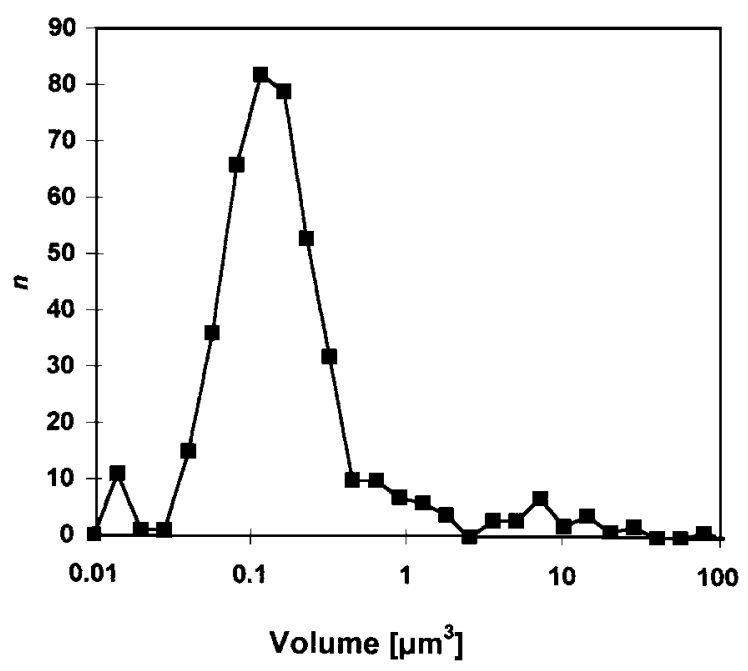

Fig. 1. Frequency distribution of bacterial volumes from Lake Redó calibration sample.

Another intercomparison was performed in one lake during one season (February to December) from the data of 9 samplings at two depths - surface and near bottom. All 18 samples were elaborated by two partners: partner A used Nuclepores and DAPI stain, partner $\mathrm{B}$ used Anopores and AO stain. The results are summarized in table 2. Regressions showed that there was not significant difference in bacterial abundance between the two partners - single data differed by less than by $10 \%$. However, cell volumes, cell lengths and, consequently, carbon biomass were consistently lower (by $40 \%$, by $40 \%$ and by $20 \%$, respectively) with partner B, indicating that with AO stain on Anopore filters, cells appeared smaller in both dimensions, especially rods (data not shown).

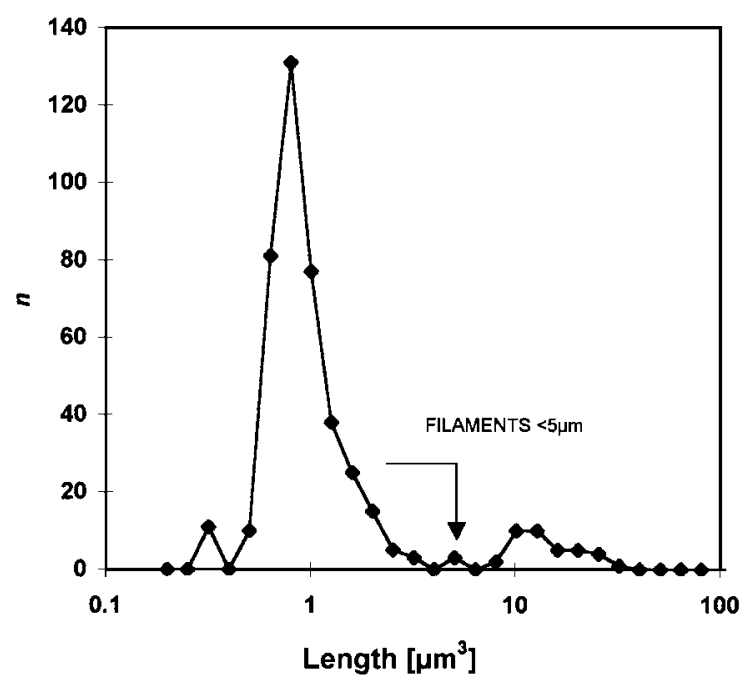

Fig. 2. Frequency distribution of bacterial lengths from Lake Redó calibration sample.

\subsection{Number and biomass of protozoans}

Heterotrophic nanoflagellates were regularly found in all lakes, but they did not often reach high numbers. HNF numbers exceeding 400 per $\mathrm{ml}$ only were found in three lakes. In 5 lakes their numbers did not exceed 60 per $\mathrm{ml}$. The cell size was highly variable even in one lake of different depths or during the season. The range of variation was one order or more in 6 lakes. Mean cell volumes varied from 2.9 up to $200 \mu \mathrm{m}^{3}$. The highest biomass found was $78 \mu \mathrm{g} \mathrm{C}^{-1}$ in one lake (Gossenköllesee, Austrian Alps - Wille et al. 1999, this issue), whereas in 7 other lakes the highest biomass observed was in the range of 9 to $40 \mu \mathrm{g} \mathrm{C}^{-1}$. In the other 4 lakes, HNF biomass remained below $5.3 \mu \mathrm{g} \mathrm{Cl}^{-1}$.

Ciliates occurred in lower numbers than HNF (almost by two orders) and usually also in lower biomass. Only in 3 lakes did their biomass exceed $10 \mu \mathrm{g} \mathrm{C}^{-1}$. In two lakes, the CIL biomass reached similar values to those of HNF biomass and in one lake (Starolesnianske, Slovak Tatra), it was even higher. In deeper lakes, CIL might show conspicuous vertical stratification and could be underestimated in discrete samples.

In general, the biomass of heterotrophic protozoans was negligible compared to the biomass of bacteria, except for short periods in particular layers (e.g., near the bottom). It should be noticed that potentially mixotrophic taxa prevailed in phytoplankton (Dinobryon and others), the bacterivory of which could not be quantified, and which might be the main bacterivores in most of the lakes. Small flagellates with a weak chlorophyll autofluorescence were often found; it was difficult to 
class them as auto- or heterotrophs, especially if they could not be analyzed immediately after sampling. Consequently, the numbers of HNF below 100 per ml cannot be considered as accurate.

\subsection{Phytoplankton biomass}

Autotrophic picoplankton (APP) was very scarce. In two lakes, it was never found. In 7 lakes, it was found occasionally, but never surpassing 600 cells per ml (corresponding to less than $0.17 \mu \mathrm{g} \mathrm{C}^{-1}$ ). In 2 lakes, values reaching thousands of cells per $\mathrm{ml}$ were found several times, but APP was absent in most samples. In Jörisee III (Switzerland) in August and October a not negligible number of APP was found $\left(1.0 \times 10^{4}\right.$ cell ml ${ }^{-1}$ or $8 \mu \mathrm{g} \mathrm{C}$ $\left.1^{-1}\right)$. One lake only (Lochnagar, Scotland) was inhabited by APP constantly and in all samples (1500 to 23,150 cells per ml or 0.7 to $9 \mu \mathrm{g} \mathrm{Cl}^{-1}$ ).

The procedure for the assessment of nanophytoplankton (PHY) volume biomass need not to be tested especially for mountain lakes. What was to be tested was the conversion factor from volume biomass to carbon, since the values used by different authors varied. For mountain lakes, flagellates are the most common group found and flagellate culture was used for the testing.

Rhodomonas sp., strain 26.28, Algal Culture Collection in Göttingen, Germany, was cultivated in a P-limited chemostat, $16 \mathrm{hrs} \mathrm{light} \mathrm{/} 8 \mathrm{hrs}$ dark cycle (Šimek et al. 1997). Suspension of live cells was subsampled in two parts. The first sample was analysed by J. Hejzlar for particulate organic carbon. The second was preserved by Lugol and analysed by M. Blažo for cell counts and cell volume. The preserved flagellates were counted after dilution $100 \times$ using the standard procedure for phytoplankton (2700 cells counted and measured). Concentration of particulate organic carbon was $59.8 \mu \mathrm{g} \mathrm{ml}^{-1}(\mathrm{v}=0.7 \%)$. The abundance was $1,309,000$ cells $\mathrm{ml}^{-1}$, the mean cell volume was $245 \mu \mathrm{m}^{3}$ (the droplike shape of Rhodomonas was approximated as the average of an ellipsoid and a cone). The resulting volumeto-carbon conversion is $0.19 \mathrm{mg} \mathrm{mm}^{-3}$. The result is considered as a confirmation of the rough a priori factor 0.2 used in this study. No attempts were made to refine this factor by modifying it for different taxonomic or size groups of phytoplankton. Most of the phytoplankters in high mountain lakes are flagellates and Rhodomonas is one of the genera occurring frequently in the lakes. This makes the use of the chosen factor more warranted.

The maximum PHY biomass found during the icefree periods (expressed per volume) varied considerably (up to 2.5 orders). In the lake Długi, PHY was extremely low, not surpassing $5 \mu \mathrm{g} \mathrm{C}^{-1}$ with one exceptionally high value $\left(15 \mu \mathrm{g} \mathrm{C} \mathrm{l}^{-1}-\right.$ Fott et al. 1999 , this issue). Lakes Stavsvatn, Øvre Neådalsvatn, Lochnagar, Nižné Terianske and Jöri showed biomass up to $60 \mu \mathrm{g} \mathrm{C}$ $1^{-1}$ (with one exceptional peak of $550 \mu \mathrm{g} \mathrm{C} 1^{-1}-$ Strašk- rabová et al. 1999b; Fott et al. 1999; Hinder et al. 1999b, this issue). In lakes Laghetto Inferiore, Redó, Chuna and La Caldera, PHY biomass increased to 150 $\mu \mathrm{g} \mathrm{C}^{-1}$ (with two peaks of around $250 \mu \mathrm{g} \mathrm{C}^{-1}-\mathrm{Si}$ mona et al. 1999, this issue; Camarero et al. 1999; Moiseenko, personal communication, Medina-Sánchez et al. 1999, this issue). Finally, in the lakes Gossenkölle and Paione Superiore, the peaks were $270 \mu \mathrm{g} \mathrm{C}^{-1}$ and $580 \mu \mathrm{g} \mathrm{C}^{-1}$, respectively (Blažo, personal communication, Pugnetti \& Bettinetti 1999, this issue). The highest PHY biomass was observed in Lake Starolesnianske, reaching $2500 \mathrm{\mu g} \mathrm{C}^{-1}$ (Fott et al. 1999, this issue).

\subsection{Zooplankton biomass}

The carbon content in a dry mass of zooplankton was tested in 17 samples of dry crustacean zooplankton (ZOOB, see 2.1.) coming from several MOLAR lakes (Stavsvatn, Nižné Terianske Pleso, Starolesnianske Pleso, Gossenköllesee, Jörisee, Lago Paione Superiore, La Caldera). Samples were analyzed in the Istituto Italiano di Idrobiologia in Pallanza for organic carbon. Results were expressed as a percentage of organic carbon in dry mass. The mean value was $49.5 \%$, the range $42 \%-57 \%$. Two additional samples of Daphnia magna (Cladocera) cultivated in excess food in an outdoor tank also fell into this range. This means that using the factor 0.5 for conversion of dry mass to organic carbon is quite reasonable, at least for cladocerans and copepods.

Comparison of direct determination of biomass with estimates from length-weight relationships might be tested on large zooplankton only. Manca \& Comoli (1999, this issue) compared determinations (by weighing) and estimates (from length-weight relationships) of the zooplankton biomass in Lago Paione Superiore. At each sampling date, both measurements were made on a pair of samples, ZOOL (preserved, for measurements and calculations) and ZOOB (for determination of dry weight). The agreement was reasonably good, especially when we take into account the variation among independent hauls.

Generally, the estimation of zooplankton biomass was fraught with difficulty. Among the components of pelagic food webs in high mountain lakes, large zooplankton are the only group where samples can be taken in such purity that direct determination of biomass (as dry mass or organic carbon) is feasible. But it happened quite often that samples contained a high proportion of particles like pollen grains or algal filaments, which made determination of biomass unreliable. Therefore, the only universal way of expressing zooplankton biomass is by indirect estimates based on measurements of dimensions and conversion factors. The elemental ratio of $\mathrm{C}: \mathrm{N}: \mathrm{P}$ in zooplankton changes according to growth stage and physiological stage, as measured in calanoid copepod from a mountain lake by Villar-Argaiz et al. (1999), so the exact stoichiometry could not be calculated using one conversion factor. 
Zooplankton biomass has been elaborated so far in 9 lakes from the 13 lakes sampled. In three of them, total zooplankton biomass reached 60 to $90 \mu \mathrm{g} \mathrm{C}{ }^{-1}$ (Chuna, Paione Superiore, Redó and La Caldera - Moiseenko, personal communication, Manca \& Comoli 1999; Camarero et al. 1999; Medina-Sánchez et al. 1999, this issue). Biomass of one order lower was found in $\emptyset_{v r e}$ Neådalsvatn, Nižné Terianske, Starolesnianske and Laghetto Inferiore, whereas in Długi Staw, zooplankton was absent (Fott, unpublished results, Simona et al. 1999). The share of ZOOS in total zooplankton varied during the season and usually did not surpass $40 \%$.

\subsection{Primary production}

The main misinterpretations of extracellular primary production and its utilisation by bacteria might occur during the separation between phytoplankton and bacteria, which is done by fractionate filtration. Each particular sample should be controlled microscopically. In oligotrophic lakes, the high proportion of ${ }^{14} \mathrm{C}$ light fixation might be due to autotrophic picoplankton (Stockner \& Shortreed 1994), which could not be size-separated from bacteria. Fortunately, in the high mountain lakes studied in MOLAR $2^{\text {nd }}$ level, APP were found to be extremely scarce and negligible. The other problem might be filamentous bacteria with volumes comparable to phytoplankton taxa. Fortunately again, this situation occurs frequently in mountain lakes, but usually at the end of ice cover. Though occasionally large bacterial cells were found, they were not so large as to make the size separation from algae impossible.

The ranges of total primary production values measured and percentage of exudation (i.e., $\mathrm{C}$ utilised by bacteria and dissolved) are shown in table 3 . In oligotrophic mountain lakes, the percentage values of extracellular production could reach 70 to $90 \%$, whereas in meso- and eutrophic lowland lakes and reservoirs they reached up to $40 \%$ (Straškrabová et al. 1999a).

\subsection{Bacterial production and elimination}

The ranges of bacterial thymidine and leucine uptake are shown in table 3 . The values of leucine uptake in 5 lakes were measured within a similar range by all the participants. Thymidine uptake, in contrast, was about one order higher in three lakes than in the other 4 lakes. In lakes Øvre Neådalsvatn, Nižné Terianske and Starolesnianské, we used ${ }^{3} \mathrm{H}$ labelled thymidine with a higher activity - 3.0 TBq/mmol (Amersham TRK 758). With the high specific activity, apparently, the conversion factor from thymidine to carbon was different (about one order lower) than with the routinely used activity $1.78 \mathrm{TBq} / \mathrm{mmol}$ (Amersham TRK 418). Calibration of the conversion factor in mountain lakes was not always possible due to low rates, and we could derive the factor only indirectly from comparison with leucine uptake or production rate estimated from elimination measurements. Surprisingly, the calibration of conver- sion factor THY to $\mathrm{C}$ measured with high specific activity thimidine in a eutrophic reservoir (Nedoma, unpublished results) revealed similar values to those with lower activity THY, consistent with literature (Bell 1990). The discrepancy between the uptakes of THY with different specific activities was found only in ultraoligotrophic lakes - the MOLAR lakes mentioned above and the acidified lakes in the Šumava Mts (Czech Republic). The only explanation might be that the high activity THY contained more low molecular products formed by disintegration through radiolysis than the "low" activity THY and these products are taken up by bacteria in ultraoligotrophic environments not only from DNA production, but also as a substrate. In meso- and eutrophic environments and/or at lower specific activities of THY, this seemed not to be significant. So the conversion from high activity THY uptake to carbon in mountain lakes was "calibrated" by comparison with LEU uptake and with the production rate estimated from elimination experiments.

Tab. 3. Primary production and bacterial production in mountain lakes - ranges of measured values in 7 lakes. GPP gross primary production expressed in carbon, EOC - extracellular production in \% of GPP, THY - bacterial uptake of thymidine (range in parentheses - with higher specific activity of thymidine), LEU - bacterial uptake of leucine.

\begin{tabular}{cccc}
\hline Parameter & Unit & \multicolumn{2}{c}{ Ranges of values measured } \\
\hline GPP & $\mu \mathrm{g} \mathrm{C} \mathrm{l}^{-1} \mathrm{~h}^{-1}$ & $0.7-2.7$ \\
EOC & $\%$ & 5 & -75 \\
THY & $\mathrm{pmol} \mathrm{l}^{-1} \mathrm{~h}^{-1}$ & $0.05-0.9$ & $(1.2-15.1)$ \\
LEU & $\mathrm{pmol} \mathrm{l}^{-1} \mathrm{~h}^{-1}$ & $0.7-50$ \\
\hline
\end{tabular}

Conversion of LEU uptake to carbon was done according to the data from lake Constance by Simon et al. (1998). The authors derived the factor $2.3 \mathrm{~g} \mathrm{C}$ per mol LEU. In a eutrophic reservoir we found a higher factor 5.7 (median of 15 measurements; Nedoma, unpublished results). Conversion to cell production by different authors is quite consistent, viz. $0.07 \times 1018$ cells per mol LEU by Tulonen (1993) in a mesohumic lake, by Berger et al. (1995) in the River Danube and by Nedoma (unpublished results) in a eutrophic reservoir.

Elimination rates found in mountain lakes were usually very low: from -0.006 to $-0.36 \mathrm{~d}^{-1}$. The corresponding production values, calculated in the same samples from the elimination experiments according to the equation (10) (section 2.10) were in the range -0.11 to $0.86 \mathrm{~d}^{-1}$. During this set of measurements, production mostly exceeded elimination, though in two cases the production rate was found to be negative. In concordance with higher production than grazing rates, bacterial numbers in the lakes mostly increased during the 3 days of study.

\subsection{Total pelagic biomass}

Total pelagic biomass (per volume in particular layers during ice-free seasons) in the 7 lakes where all the 
components were elaborated, fell within the range of 10 to $3000 \mu \mathrm{g} \mathrm{C}^{-1}$. Lake Długi showed extremely low values: as $12 \mu \mathrm{g} \mathrm{Cl}^{-1}$, with one exceptional peak one order higher, which was due to an extremely high bacterial biomass. In Øvre Neådalsvatn and Nižné Terianske, total biomass never surpassed $60 \mu \mathrm{g} \mathrm{C}^{-1}$. In lakes Redó, La Caldera and Paione Superiore, biomass might be as high as $100 \mu \mathrm{g} \mathrm{C}^{-1}$, exceptionally $200 \mu \mathrm{g} \mathrm{C}^{-1}$, which was sometimes due to high $\mathrm{ZOO}$, and in other cases to high PHY development. The highest biomass, close to $3000 \mu \mathrm{g} \mathrm{C}^{-1}$, was observed in Lake Starolesnianske, with the highest occurrence of PHY.

Considering vertical distribution, the surface layers showed the lowest biomass in most cases, with the peaks occurring at deeper levels, sometimes close to the bottom. This is valid especially for the PHY and ZOO components and was observed even in fishless lakes, which indicates an effect of photoinhibition. A striking example is Lake Paione Superiore, described in this issue (Callieri et al. 1999, this issue).

\section{CONCLUSIONS}

Bacterial numbers counted on Nuclepore filters stained with DAPI compare well among different analysts. Volumes, and consequently carbon biomass estimates, varied more among the partners, especially if filamentous bacteria were numerous, and the image analysis system (incl. screen colour) used should have comparable parameters in order to achieve consistent results.

Numbers of autotrophic picoplankton and heterotrophic flagellates were mostly very low, with the accuracy of the results depending not only on the analyst, but also on the time elapsing between sampling and elaboration in the laboratory. Ciliates were also very scarce, but after preservation they could be elaborated accurately.

The carbon content of phytoplankton biomass was tested on flagellates and the conversion factor volumeto-carbon equal to $0.2 \mathrm{mg} \mathrm{mm}^{-3}$ approved. The carbon content of zooplankton biomass was tested on large zooplankton and found to agree with the estimates based on length-weight relationships.

The total pelagic biomass in the lakes under study fell within the range of 10 to $3000 \mu \mathrm{g} \mathrm{C}^{-1}$. The three main components are bacterioplankton, phytoplankton and zooplankton. In different lakes, any one of these components might be prevalent in seasonal peaks. The maximum biomass of all the lakes was found to be dominated by phytoplankton (Starolesnianske Lake).

The measurement of primary production and exudation in remote mountain lakes was possible by the proposed procedure and documented a significant supply by organics (available to bacteria) from exudates.

Bacterial production from thymidine uptake was only comparable if the same specific activity of labelled thymidine was used. In addition, a validation of THY to carbon conversion factor from a comparison with leucine uptake and production rate estimated from elimination experiments is necessary. Elimination rates were often lower than production rates and this is in concordance with the scarcity of potential bacterivores (though the potential bacterivory by mixotrophic flagellates could not be estimated).

\section{ACKNOWLEDGMENTS}

This research was supported by MOLAR (ENV4CT95-0007) within the EU Environment and Climate Programme and INCO, and by the Ministry of Education, Youth and Sports of the Czech Rep.(project OK 118). We are indebted to R. Harriman, J. Keay, L. Lien, T. Moiseenko, J. Galas, E. Stuchlík, F. Šporka, M. Blažo, J. Kopáček, M. Felip, L. Camarero and others for sampling, sending samples and providing additional related data. Thanks are due to the project co-ordinators, B. Wathne and S. Patrick and also to the many MOLAR participants for constant support, encouragement and useful discussions.

\section{REFERENCES}

Barbieri, A., M. Veronesi, M. Simona, S. Malusardi \& V. Straškrabová. 1999. Limnological survey in eight high mountain lakes located in Lago Maggiore watershed (Switzerland). In: Straškrabová, V., C. Callieri \& J Fott (Eds), Pelagic food web in mountain lakes. MOuntain LAkes Research Program. J. Limnol., 58(2): 179-192.

Baron, J.S., D. McKnight \& A.S. Denning. 1991. Sources of dissolved and particulate organic material in Loch Vale watershed, Rocky-Mountain-National-Park, Colorado, USA. Biogeochemistry, 15: 89-110.

Bell, R.T. 1990. An explanation of the variability in the conversion factor deriving bacterial cell production from incorporation of $\left[{ }^{3} \mathrm{H}\right]$ thymidine. Limnol. Oceanogr., 35: 910-915.

Berger, B., B. Hoch, G. Kavka \& G.J. Herndl. 1995. Bacterial metabolism in the River Danube: parameters influencing bacterial production. Freshwat. Biol., 34: 601-616.

Bloem, J., M.J.B. Bar-Glissen \& T.E. Cappenberg. 1986. Fixation, counting and manipulation of heterotrophic nanoflagellates. Appl. Environ. Microbiol., 52: 1266-1272.

Borsheim, K.Y. \& G. Bratback. 1987. Cell volume to carbon conversion factors for bacterivorous Monas sp. enriched from seawater. Mar. Ecol. Prog. Ser., 36: 171-175.

Chisholm, S.W. 1992. Phytoplankton size. In: P.G. Falkowski \& A.D. Woodhead (Eds), Primary productivity and biogeochemical cycles in the sea. Plenum Press, New York: 213-237.

Callieri, C. \& R. Bertoni. 1999. Organic carbon and microbial food web assemblages in an oligotrophic alpine lake. In: Straškrabová, V., C. Callieri \& J Fott (Eds), Pelagic food web in mountain lakes. MOuntain LAkes Research Program. J. Limnol., 58(2): 136-143.

Callieri, C., A. Pugnetti \& M. Manca. 1999. Carbon partitioning in the food web of a high mountain lake: from bacteria to zooplankton. In: Straškrabová, V., C. Callieri \& J Fott (Eds), Pelagic food web in mountain lakes. MOuntain LAkes Research Program. J. Limnol., 58(2): 144-151.

Camarero, L., M. Felip, M. Ventura, F. Bartumeus \& J. Catalan. 1999. The relative importance of the planktonic food web in the carbon cycle of an oligotrophic mountain lake in a poorly vegetated catchment (Redó, Pyrenees). In: 
Straškrabová, V., C. Callieri \& J Fott (Eds), Pelagic food web in mountain lakes. MOuntain LAkes Research Program. J. Limnol., 58(2): 203-212.

Carrillo, P., I. Reche \& L. Cruz-Pizarro. 1996a. Intraspecific stoichiometric variability and the ratio of nitrogen and phosphorus resupplied by zooplankton. Freshwat. Biol., 36: 363-374.

Carrillo, P., I. Reche \& L. Cruz-Pizarro. 1996b. Quantification of the phosphorus released by zooplankton in an oligotrophic lake (La Caldera, Spain): regulating factors and adjustment to theoretical models. J. Plankton Res., 18: $1567-1586$

Felip, M. 1997. Ecologia del microplankton d'un estany profundo d'alta muntanya (Redó, Pirineus). $\mathrm{PhD}$ thesis, Universitat de Barcelona, Facultat de Biologia, Departament d'Ecologia.

Felip, M., F. Bartumeus, S. Halac \& J. Catalan. 1999. Microbial plankton assemblages, composition and biomass, during two ice-free periods in a deep high mountain lake (Estany Redó, Pyrenees). In: Straškrabová, V., C. Callieri \& J Fott (Eds), Pelagic food web in mountain lakes. MOuntain LAkes Research Program. J. Limnol., 58(2): 193-202.

Fott, J., M. Blažo, E. Stuchlík \& O. Strunecký. 1999. Phytoplankton in three Tatra mountain lakes of different acidification status. In: Straškrabová, V., C. Callieri \& J Fott (Eds), Pelagic food web in mountain lakes. MOuntain LAkes Research Program. J. Limnol., 58(2): 107-116.

Fott, J., E. Stuchlík, Z. Stuchlíková, V. Straškrabová, J. Kopáček \& K. Šimek. 1992. Acidification of lakes in Tatra Mountains (Czechoslovakia) and its ecological significance. In: Mosello, R., Wathne, B. \& Giussani, G. (Eds), Limnology on groups of remote mountain lakes: ongoing and planned activities. Documenta Ist. ital. Idrobiol., 32: 69-81.

Hall, J.A. 1991. Long-term preservation of picophytoplankton for counting by fluorescence microscopy. Br. Phycol. J., 26: 169.

Hinder, B., I. Baur, K. Hanselmann \& F. Schanz. 1999a. Microbial food web in an oligotrophic high mountain lake (Jöri Lake III, Switzerland). In: Straškrabová, V., C. Callieri \& J Fott (Eds), Pelagic food web in mountain lakes. MOuntain LAkes Research Program. J. Limnol., 58(2): 162-168.

Hinder, B., M. Gabathuler, B. Steiner, K. Hanselmann \& H. R. Preisig. 1999b. Seasonal dynamics and phytoplankton diversity in high mountain lakes (Jöri lakes, Swiss Alps). In: Straškrabová, V., C. Callieri \& J Fott (Eds), Pelagic food web in mountain lakes. MOuntain LAkes Research Program. J. Limnol., 58(2): 152-161.

Hayat, M.A. 1981. Fixation for electron microscopy. Academic press. NY. $500 \mathrm{pp}$

Jones, R.I. 1994. Mixotrophy in planktonic protists as spectrum of nutritional strategies. Mar. Microbiol. Food Webs, 8: 87-96.

Kuuppo-Leinikki, P. \& H. Kuosa. 1989. Preservation of picoplanktonic cyanobacteria and heterotrophic nanoflagellates for epifluorescence microscopy. Arch. Hydrobiol., 114: 631.

Laybourn-Parry, J., P. Bayliss \& J.C. Evans. 1995. The dynamics of heterotrophic nanoflagellates and bacterioplankton in a large ultre-oligotrophic Antarctic lake. $J$. Plankton Res., 17: 1835-1850.

Legner, M. \& W.G. Sprules. 1993. Preservation and computer aided microscopic analysis of planktonic protozoa and algae. J. Aquatic Ecosystems Health, 2: 221-227.

MacIsaac, E.A. \& J.G. Stockner. 1993. Enumeration of phototrophic picoplankton by autofluorescence microscopy In: P. Kemp, B. Sherr, E. Sherr \& J. Cole (Eds), Handbook of methods in aquatic microbiology. Lewis Publishers, Boca Raton: 229-240.
Manca, M. \& P. Comoli. 1999. Studies on zooplankton of Lago Paione Superiore. In: Straškrabová, V., C. Callieri \& J Fott (Eds), Pelagic food web in mountain lakes. MOuntain LAkes Research Program. J. Limnol., 58(2): 131-135.

Medina-Sánchez, J.M., M. Villar-Argaiz, P. Sánchez-Castillo, L. Cruz-Pizarro \& P. Carrillo. 1999. Structure changes in a planktonic food web: biotic and abiotic controls. In: Straškrabová, V., C. Callieri \& J Fott (Eds), Pelagic food web in mountain lakes. MOuntain LAkes Research Program. J. Limnol., 58(2): 213-222.

Mosello, R., A. Boggero, A. Marchetto, B. Wathne \& L. Lien. 1998. Chemistry of headwater lakes studied in the EU project Acidification of mountain lakes: palaeolimnology and ecology (AL:PE). - In: K. Kovar, U. Tappeiner, N.E. Peters, R.G. Craig (Eds), Hydrology, water resources and ecology in headwaters. Proceedings of the HeadWater'98 conference, Merano. International Association of Hydrological Sciences Publ. No. 248, IAHS Press, Wallingford: 395-401.

Möller, H. \& W. Geller. 1993. Maximum growth rates of aquatic ciliated protozoa: the dependence on body size and temperature reconsidered. Arch. Hydrobiol., 126: 315-327.

Norland, S. 1993. The relation between biomass and volume of bacteria. In: P. Kemp, B. Sherr, E. Sherr \& J. Cole (Eds), Handbook of methods in aquatic microbiology. Lewis Publishers, Boca Raton: 303-308.

Pace, M.L. \& J.D. Orcutt Jr. 1981. The relative importance of protozoans, rotifers and crustaceans in a freshwater zooplankton community. Limnol. Oceanogr., 26: 822-830.

Patrick, S., R.W. Battarbee, B. Wathne \& R. Psenner. 1998: Measuring and modelling the dynamic response of remote mountain lake ecosystems to environmental change: an introduction to the MOLAR project. - In: K. Kovar, U. Tappeiner, N.E. Peters, R.G. Craig (Eds), Hydrology, water resources and ecology in headwaters. Proceedings of the HeadWater'98 conference, Merano. International Association of Hydrological Sciences Publ. No. 248, IAHS Press, Wallingford: 403-410.

Porter, K.G. \& Y.S. Feig. 1980. The use of DAPI for identifying and counting aquatic microflora. Limnol. Oceanogr., 25: 943-948.

Psenner, R. 1993. Determination of size and morphology of aquatic bacteria by automated image analysis. In: P. Kemp, B. Sherr, E. Sherr \& J. Cole (Eds), Handbook of methods in aquatic microbiology. Lewis Publishers, Boca Raton: 339-345.

Pugnetti, A. \& R. Bettinetti. 1999. Biomass and species structure of the phytoplankton of an high mountain lake (Lake Paione Superiore, Central Alps, Italy). In: Straškrabová, V., C. Callieri \& J Fott (Eds), Pelagic food web in mountain lakes. MOuntain LAkes Research Program. J. Limnol., 58(2): 127-130.

Putt, M. \& D.K. Stoecker. 1989. An experimentally determined carbon:volume ratio for marine „oligotrichous“" ciliates from estuarine and coastal waters. Limnol. Oceanogr., 34: 1097-1103.

Reche, I., P. Carrillo \& L. Cruz-Pizarro. 1997. Influence of metazooplankton on interactions of bacteria and phytoplankton in an oligotrophic lake. J. Plankton Res., 19: 631-646.

Reche, I., P. Carrillo, P. Lavandier \& L. Cruz-Pizarro. 1998. Comparative analysis of bacteria-phytoplankton relationship in two ecosystems of different trophic status. Verh. int. Ver. Limnol., 26: 1645-1649.

Reche, I., A. Pugnetti, L. Cruz-Pizarro \& P. Carrillo. 1996. Relationship between bacteria and phytoplankton in a high-mountain lake: Importance of the organic carbon released by pelagic algae for bacterioplankton. Arch. Hydrobiol. Spec. Issue Advanc. Limnol., 48: 31-38.

Reynolds, C.S. 1984. The ecology of freshwater phytoplankton. Cambridge University Press: 384 pp. 
Rocha, O. \& A. Duncan. 1985. The relationship between cell carbon and cell volume in freshwater algal species used in zooplanktonic studies. J. Plankton Res., 7: 279-294.

Ruttner-Kolisko, A. 1977. Suggestions for biomass calculations of plankton rotifers. Arch. Hydrobiol. Beih. Ergebn. Limnol., 8: 71-76.

Salat, J. \& C. Marrase. 1994. Exponential and linear estimations of grazing on bacteria: effects of changes in the proportion of marked cells. Mar. Ecol. Progr. Ser., 104: 205209.

Sherr, E.B. \& B.F. Sherr. 1993a. Preservation and storage of samples for enumeration of heterotrophic protists. In: P. Kemp, B. Sherr, E. Sherr \& J. Cole (Eds), Handbook of methods in aquatic microbiology, Lewis Publishers, Boca Raton: 207-212.

Sherr, E.B. \& B.F. Sherr. 1993b. Protistan grazing rates via uptake of fluorescently labelled prey. In: P. Kemp, B. Sherr, E. Sherr \& J. Cole (Eds), Handbook of methods in aquatic microbiology, Lewis Publishers, Boca Raton: 695701

Simon, M. \& C. Wunsch. 1998. Temperature control of bacterioplankton growth in a temperate large lake. Aquatic $\mathrm{Mi}$ crob. Ecol., 16: 119-130.

Simon, M., M.M. Tilzer \& H. Müller. 1998. Bacterioplankton dynamics in a large mesotrophic lake: I. abundance, production and growth control. Arch. Hydrobiol., 143: 385407.

Simona, M., A. Barbieri, M. Veronesi, S. Malusardi \& V. Straškrabová. 1999. Seasonal dynamics of plankton in a mountain lake in the southern Alps (Laghetto Inferiore, Switzerland). In: Straškrabová, V., C. Callieri \& J Fott (Eds), Pelagic food web in mountain lakes. MOuntain LAkes Research Program. J. Limnol., 58(2): 169-178.

Stockner, J.G. 1988. Phototrophic picoplankton: An overview from marine to freshwater ecosystems. Limnol. Oceanogr., 33: 765-775.

Stockner, J.G. 1991. Autotrophic picoplankton in freshwater ecosystems: the view from the summit. Int. Rev. Hydrobiol., 76: 483-492.

Stockner, J.G. \& K.S. Shortreed. 1994. Autotrophic picoplankton community dynamics in a pre-alpine lake in British Columbia, Canada. Hydrobiologia, 274: 133-142.

Stockner, J., C. Callieri \& G. Cronberg. 1999. Picoplankton and other non-bloom forming cyanobacteria in lakes. In: B. Whitton \& M. Potts (Eds), Ecology of cyanobacteria: their diversity in time and space, Kluwer Academic Publishers.

Straškrabová, V. \& K. Šimek. 1988. Measurement of biomass and activity in relation to structure and function of microbial activities in plankton. Arch. Hydrobiol. Beih., Ergebn. Limnol., 31:55-60.

Straškrabová, V., K. Šimek. 1993. Microbial loop in lakes and reservoirs related to trophy and metazooplankton development. Verh. int. Ver. Limnol., 25: 1183-1186.
Straškrabová V., K. Šimek \& J. Nedoma. 1999a. Importance of pelagic bacteria in lakes and reservoirs of different trophy -Implications for long-term monitoring. In: Sustainable Lake Management, 8th International Conf. on the Conservation and Management of Lakes, 17-21 May 1999, Copenhagen-Denmark, Vol. II, S7C-5.

Straškrabová, V., K. Šimek, M. Macek, P. Hartman, J. Fott \& M. Blažo. 1999b. Pelagic food webs and microbial loop in low-alkalinity mountain lakes. Verh. int. Ver. Limnol.: in press.

Šimek, K., J. Vrba, J. Pernthaler, T. Posch, P. Hartman, J. Nedoma \& R. Psenner. 1997. Morphological and compositional shifts in an experimental bacterial community influenced by protists with contrasting feeding modes. Appl. Environ. Microbiol., 63: 587-595.

The MOLAR Water Chemistry Group. 1999. The MOLAR Project: atmospheric deposition and lake water chemistry. In: Straškrabová, V., C. Callieri \& J Fott (Eds), Pelagic food web in mountain lakes. MOuntain LAkes Research Program. J. Limnol., 58(2): 88-106.

Tilzer, M. 1972. Dynamik und Produktivität von Phytoplankton und pelagischen Bakterien in einem Hochgebirgsee (Vorderer Finstertaler See, Osterreich). Arch. Hydrobiol. Suppl., 40: 201-273.

Tóth, L.G., P. Carrillo \& L. Cruz-Pizarro. 1995. Respiratory electron transport system (ETS)-activity of the plankton and biofilm in the high-mountain lake La Calderra (Sierra Nevada, Spain). Arch. Hydrobiol., 135: 65-78.

Tulonen, T. 1993. Bacterial production in a mesohumic lake estimated from $\left[{ }^{14} \mathrm{C}\right]$ leucine incorporation rate. Microb. Ecol., 26: 201-217.

Villar-Argaiz, M., J. Medina-Sánchez, L. Cruz-Pizarro \& P. Carrillo. (1999). Life history implications of calanoid Mixodiaptomus laciniatus in C:N:P stoichiometry. Verh. int. Ver. Limnol.: in press.

Vollenweider R.A. (Ed.). 1974. A Manual on Methods for Measuring Primary Production in Aquatic Environments. 2nd edition, IBP Handbook No. 12, Blackwell scientific Publications: $225 \mathrm{pp}$.

Weisse, T. 1993. Dynamics of autotrophic picoplankton in marine and freshwater ecosystems. In: J.G. Jones (Ed.), Advances in microbial ecology. 13, Plenum Press, New York: 327-370.

Wiaczkowski, K., A. Doniec \& J. Fyda. 1994. An empirical study of the effect of fixation on ciliate volume. Mar. Ecol. Food Webs, 8: 59-69.

Wille, A., B. Sonntag, B. Sattler \& R. Psenner. 1999. Abundance, biomass and size-structure of the microbial assemblage in the high mountain lake Gossenköllesee (Tyrol, Austria) during the ice-free period. In: Straškrabová, V., C. Callieri \& J Fott (Eds), Pelagic food web in mountain lakes. MOuntain LAkes Research Program. J. Limnol., 58(2): 117-126. 